\title{
АФИРМАЦИЈА СОЦИОЛОШКОГ ПРИСТУПА ИДЕНТИТЕТУ У ТЕОРИЈИ НОРБЕРТА ЕЛИЈАСА ${ }^{2}$
}

Сажетак: Рад се бави концептом идентитета као процеса, приступом који је снажно заговарао Норберт Елијас. Његова „процесна социологија“ била је настојање да се превазиђу дуалности које су оптерећивале социолошку теорију. Елијас је покренуо критику теоријског постваривања друштвене структуре као објекта који је изван појединца и независан од њега. Истовремено, он је одбацио оно што је назвао homo clausus (концепт у којем се нагласак ставља на аутономију, слободу и независност актера) као прекомерни индивидуализам, у складу са којим се друштво схвата као намеравани исход појединачних делања. У својој теорији идентитета, Елијас је, између осталог, користио појмове хабитуса, фигурације и ,ја-“ и „ми-идентитета“. Он је писао о хабитусу као о „другој природи“ или „механизму аутоматске и слепе сомоконтроле“, који се на индивидуалном нивоу доживљава као структура личности, али који је колективно произведен и репродукован током целог живота. Елијас је индивидуални идентитет препознао као временску творевину, те његова теоријска перспектива дозвољава анализу промена у односу ,ја-ми“, без давања предности било ком елементу овог пара. Такође, идентитет је замишљен као мултиперспективистички (релациони) и обликован фигурацијама (ланцима међузависности).

Кључне речи: процес, идентитет, хабитус, фигурација, ,ја-“ и „ми-идентитети“.

\section{Увод}

Крајем XX, а нарочито почетком XXI века обнавља се интересовање за дело Норберта Елијаса (Norbert Elias). Занимање за његов рад било је тако вели-

\footnotetext{
${ }^{1}$ milos.jovanovic@filfak.ni.ac.rs

2 Први нацрт овог рада представљен је на међународној научној конференцији Култура и идентитети, одржаној од 25. до 27. октобра 2019. године у Мећавнику и Андрићграду у организацији Српског социолошког друштва, Социолошког друштва Републике Српске и Института за политичке студије.

Коначна верзија је урађена у оквиру пројекта Корак ка професионализацији социологије 2: анализа потреба за професијом, који реализује Департман за социологију Филозофског факултета Универзитета у Нишу. Ово истраживање финансијски је подржало Министарство просвете, науке и технолошког развоја Републике Србије.
} 
ко да је Денијел Гордон написао: „Да је наука о друштву спорт, Норберт Елијас (1897-1990) би добио награду за повратак (comeback) столећа“ (Gordon 2002: 68). О овоме сведочи број монографија и зборника посвећених Елијасовој социологији (Dépelteau \& Landini 2013; Dunning \& Hughes 2013; Elias, Goudsblom \& Mennell 1998; Heinich 2002; Kilminster 2007; Landini \& Dépelteau 2014, 2017; Mennell 1992; Smith 2001; Van Krieken 1998), као и бројни чланци из часописа и поглавља у хрестоматијама ${ }^{3}$. Додатни показатељи ове повећане пажње чине и публицистички подухвати, најпре издавачке куће $S A G E$ која је 2003. године, у оквиру едиције Мајстори савремене мисли о друштву (Masters in Modern Social Thought), објавила четворотомни зборник радова посвећених Елијасовој социологији, а затим и издавачког центра Универзитетског колеџа из Даблина (University College Dublin Press) који је у периоду од 2005. до 2014. године на енглеском језику објавио сабрана дела Норберта Елијаса у 18 томова ${ }^{4}$

Крајем деведесетих година прошлог века уобличава се један од покрета у савременим друштвеним наукама који је означен као „релационистички заокрет“ (relational turn). Овај прилично хетерогени скуп научних подухвата (видети: Crossley 2011; Dépelteau 2018; Dépelteau \& Powell 2014; Emirbayer 1997; Powell \& Dépelteau 2013) један је од покушаја превазилажења кризе у социологији, али и у модерним друштвима уопште. Релационистички приступ своју „перспективу“ дугује управо социолошкој концепцији коју је елаборирао Елијас, тако да „повратак“ и реактуелизација његовог опуса у том контексту добијају пуни смисао.

\section{Релационизам}

„'Релационистички заокрет’ у друштвеној теорији (...) обећава превазилажење апстрактних и статичких филозофских категорија и здраворазумско свођење друштвених односа, процеса и структура на појединачне физичке ствари“ (Law 2015: 276). На здраворазумском нивоу се чини очигледним да су друштво, односно било која група, и људска јединка одвојени ентитети. Но, релационизам „инсистира на тачкама повезаности између ствари, а не стварима по себи. Све појединачне 'ствари’ обликоване су међусобним контактом једних

\footnotetext{
${ }^{3}$ Можда овде треба навести и податак да је 1998. године Међународно социолошко удружене (International Sociological Association) Елијасов Процес ицвилизације навело као седму најважнију социолошку књигу XX века (видети: https://www.isa-sociology.org/en/about-isa/history-of-isa/ books-of-the-xx-century/ranking-order).

${ }^{4}$ Елијасов magnum ориs - Процес иивилизације је код нас преведен (Елијас 2001), као и његова књига Шйа је социолог̈ија? (Elias 2007). Изводи из првог тома Über den Process der Zivilisation „О повезаности контроле нагона и облика породице, односно друштвене структуре“ објављени су у социолошкој хрестоматији Рађање модерне йородище (Елијас 1988). Интервју са Елијасом: „Нисмо научили да довољно контролишемо природу и себе“ објављен је у другом броју Журнала за социолог̈ију (Елијас 2004), а његов чланак, оригинално објављен 1971. године, „Социологија знања: нове перспективе“ у зборнику Друшитво и знаюе (Елијас 2015).
} 
са другима“. Примењен на проблем односа индивидуе и друштва, овај приступ се сажима у исказ да „,[н]е постоји друштво без појединаца и нема индивидуа без друштва“" (ibid.).

Наравно, овакво наглашавање свеопште повезаности није нов, нити искључиво социолошки приступ. Тако код Анрија Бергсона (Bergson) наилазимо на еминентно релационистичко запажање:

Уопштеније узев, зар фикција једног изолованог материјалног предмета не подразумева неку врсту апсурдности, јер тај предмет позајмљује физичка својства од односа̂ које одржава са свима осталима, и свако од својих одређења, а сходно томе и само своје постојање, дугује месту које заузима у универзуму као целини? (Бергсон 2013: 24-25)5

Георг Зимл у једном од поглавља Социологије - „Како је друштво могуће?“, наглашава да индивидуа препознаје себе у спољашњем свету кроз друштвене односе (видети: Simmel 2009: 40-52). Још раније Маркс констатује да „капитал није нека ствар, већ друштвени однос међу лицима, однос који посредују ствари“ (Маркс 1964: 470), те да се друштво „не састоји од индивидуа, већ изражава суму оних повезаности, односа у којима се те индивидуе међусобно налазе“ (Marx 1979: 147).

Свој најзрелији облик, пре Елијаса, релационизам добија у раду Карла Манхајма (Mannheim) за кога ,[р]елационизам значи само узајамни однос свих елемената смисла у њихову смисаоност која се узајамно заснива у једном одређеном систему“ (Манхајм 1978: 85) ${ }^{6}$. Будући да је од 1930. до 1933. године Елијас у Франкфурту био Манхајмов асистент, разумљив је утицај који је професор оставио на свог сарадника. Елијас је, најчешће прећутно, разрађивао бројне идеје свог (само четири године) старијег колеге, међу којима запажено место заузима она коју је Манхајм дао у облику својеврсног завештања: „Можда виши задатак лежи управо у томе да научимо да мислимо релационално и динамички, а не статички“ (Манхајм 1978: 86). Критика концептуалног апарата који друштвене процесе „своди на стања“ (Zustandsreduktion) чини окосницу Елијасове „процесне социологије“.

\footnotetext{
${ }^{5}$ Упоредити са Бурдијеом: „Тежина/снага утицаја која је приписана делатнику, који се подвргава силама поља у исто време док помаже његовом структурисању, зависи од свих других делатника, од свих других тачака у простору и међуодноса свих тачака, то јест од простора у целости“ (Bourdieu 2004: 33).

${ }^{6}$ У огледу „Надметање као културна појава“ Манхајм разликује релативизам „по којем је свако и нико у праву“ од релационизма „који каже да се одређене (квалитативне) истине не могу појмити или формулисати осим у оквиру егзистенцијалне корелације између субјекта и објекта (...) то значи да су одређени увиди о неком квалитативном виду животног процеса историје доступни свести само ако су формирани одређеним историјским и друштвеним околностима, па историјско-друштвено формирање субјекта који мисли и зна стиче епистемолошки значај“ (Манхајм 2009: 239).
} 


\section{Основе Елијасовог социолошког приступа}

Јохан Хаудсблум формулише четири општа начела или полазна принципа Елијасовог социолошког приступа (Goudsblom 1977: 6):

1) Људска бића су међузависна, на различите начине; њихови се животи развијају у, и у значајној мери су обликовани, друштвеним фигурацијама које међусобно формирају.

2) Ове фигурације су у сталном превирању, и трпе промене различитог реда - неке брзе и краткотрајне, друге спорије, али можда трајније.

3) Дуготрајни процеси развоја који се дешавају у људским друштвеним фигурацијама су били и настављају да у највећој мери буду непланирани и непредвиђени.

4) Развој људског знања се дешава унутар људских фигурација и чини важан аспект њиховог целокупног развоја; развој социологије треба да буде сагледан у овом контексту: као аспект углавном непланираног и непредвиђеног развоја индустријских друштава у оквиру (националних) држава.

Заједнички живот у условима узајамне зависности представља општу основу за постојање свих људска бића, од рођења до смрти. Због тога су људи, суштински, везани једни за друге. Људе и њихово понашање можемо да схватимо само кроз разнолике фигурације којима су припадали у прошлости и које настављају да формирају у садашњости. Психогенеза и соииогенеза чине два аспекта истог процеса (Conde 2016: 42), у коме структура личности „одговара“ социјалном окружењу, које та одређена врста личности перпетуира. Прва замка коју треба избећи је разматрање људског бића у једнини, одвојеног и независног од других људи - као homo clausus (,затвореног човека“ - видети График $1)^{7}$, стога је Елијасова наука о друштву „социологија друштва са индивидуама и друштва индивидуа“" ("sociology of society with and of the individual”) (Conde

\footnotetext{
7 „Људи којима се чини самоочигледним да њихово сопство (или њихов его, њихово 'Ја', или како год да се то зове), постоји такорећи 'унутар' њих, одвојено од свих осталих људи и ствари који се налазе 'споља', тешко могу да припишу значење свим овим чињеницама које указују на то да појединци од малих ногу живе у међузависности с другима. Њима је тешко да појединце замисле као релативно, а не апсолутно аутономне, као релативно, а не апсолутно независне појединце који међусобно граде променљиве структуре. Будући да овакво самоопажање изгледа очито онима који на њега пристају, они се лако могу прихватити чињенице које указују на то да је оваква врста опажања као таква ограничена на одређена друштва, да произлази из одређених врста међузависности, друштвених веза између људи, укратко, да ово опажање припада структурној посебности одређеног ступња развоја цивилизације, специфичној диференцијацији и индивидуализацији у људским заједницама. Човек, уколико расте у таквој заједници, не може лако замислити да има и људи који себе не доживљавају на овај начин, као потпуно самодовољне појединце одвојене од свих осталих бића и ствари. Овај начин самоопажања изгледа по себи јасан, изгледа као симптом вечног људског стања, као нормално, природно самоопажање, својствено свим људима. Схватање да је појединац homo clausus, мали свет што живи сам у себи, који у крајњој линији постоји сасвим независно од великог спољног света, одређује слику човека уопште. Сваки други човек се исто тако појављује као један homo clausus; његово језгро, његово биће, његово сопство, појављује се такође као нешто у њему одвојено невидљивим зидом од свега спољног, дакле и од свих осталих људи“ (Елијас 2001: 31).
} 
2016: 42), што је прегнантно сажето управо у наслову његове књиге из 1987. године: Die Gesellschaft der Individuen (енглески превод: Elias 1991).

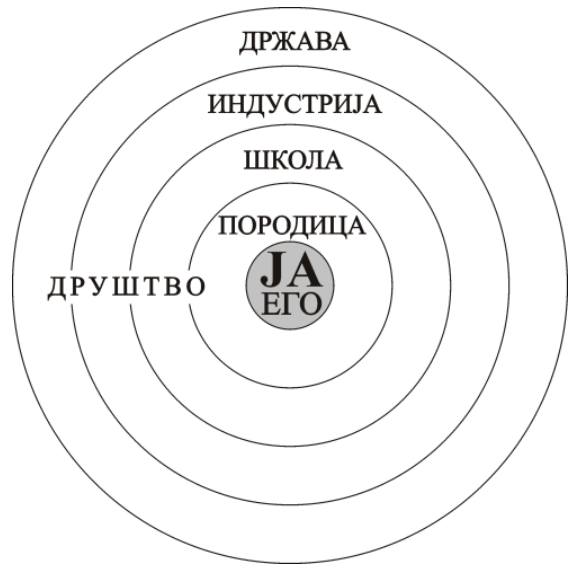

График 1: Основна шема егочентричног погледа на друштво (преузето из: Elias 1978: 14)

Друга грешка која се често прави је схватање људских јединки и друштва као статичних датости, где се занемарује стална променљивост и развој - чему умногоме доприноси појмовни апарат „подешен“" на сталност уместо промене али и неприметност (неких) промена које се дешавају релативно споро током дугих временских периода (long durée процеси, попут настајања нација). Зато Елијас инсистира на употреби термина цุивилизовање уместо цุивилизације монополизовање уместо монопола, идентификовање уместо идентитета, да би нагласио процесуални карактер друштвених појава, насупрот њиховом сагледавању као статичних ${ }^{10}$.

Људи су, чак и у случајевима када имају велику моћ и знање, тек у ограниченој мери способни да предвиде правац развоја и тако контролишу фигуращије које заједнички формирају, што је одлика друштвеног живота на коју су, између осталих, указивали и Роберт Мертон (Merton 1936) и Карл Попер (Popper 2002: 336-346).

\footnotetext{
8 „Наши језици су изграђени тако да у многим случајевима стално кретање, континуирану промену, можемо да изразимо само тако да им у говору и мишљењу дамо карактер једног изолованог предмета у стању мировања и онда, готово само као допуну, кроз додавање глагола дамо до знања да се оно што се чини као мирујуће заправо креће. Кад на пример стојимо крај реке и пред нашим очима у мислима појмовно обухватимо континуирано протицање воде и кад то желимо да изразимо у комуникацији с другима, онда не мислимо и говоримо на пример овако: 'Види стално протицање воде'; кажемо и мислимо: 'Види како брзо тече река'. Кажемо: 'Ветар дува', као да је ветар најпре неко мирујуће нешто које у неком одређеном тренутку почиње да се креће и почиње да дува - као да је ветар нешто друго од дувања, као да постоји ветар који не дува“" (Elias 1978: 111-112).
}

9 Тако би исправнији превод наслова његовог главног дела био: О йроцесу циивилиовања.

${ }^{10}$ Још неке „процесуалне именице“ које је сковао Елијас су: courtisation, sportisation, scientification. Њиховом конзистентном употребом је стално скретао пажњу на постварујући потенцијал социолошких појмова попут класе (Quilley \& Loyal 2005: 814). 
Да би Елијасов приступ проблему идентитета био разјашњен потребно је посветити пажњу појмовима хабитуса и фигурације, као и концептуалном пару „ја“ и „ми“ идентитета.

\section{Хабитус}

Иако се концепт хабитуса у социологији најчешће везује за Пјера Бурдијеa (Bourdieu), који га је, можда више него остали, разрадио и популаризовао, Елијас га је (као и Вебер [Weber]) пре њега употребљавао као теоријски алат ${ }^{11}$.

Овај појам је, како је Елијас тврдио, један од кључева за разрешавање лажне дихотомије између индивидуе и друштва, као и за превазилажење других дуалности које оптерећују социолошку теорију - агенсности и структуре, слободе и детерминизма, индивидуализма и холизма, синхроности и дијахроније, те макро и микро нивоа анализе.

Хабитус је корисна реч која се односи на начине понашања, типове укуса и врсте осећања које преовлађују међу припадницима одређених група. Може да се односи на заједничке особине које људи деле, а којих могу да скоро у потпуности буду несвесни (Mennell 1994: 177).

Хабитус се односи на оно што људи зову „другом природом“, на стечене склоности које су постале инстинктивне и тиме подразумевајуће. Оно што треба нагласити је да „диспозиције хабитуса (...) нису непроменљиве; оне се мењају кроз индивидуална делања и рефлексивност“"(Conde 2016: 43). Елијас је хабитус

сматрао изграђеним како из „индивидуалних“, тако и „друштвених“ елемената. На индивидуалном нивоу, постоји низ научених диспозиција понашања које су јединствене за индивидуу. На друштвеном нивоу се налази скуп личних карактеристика које индивидуе деле са другим члановима „њихове“ групе. Друштвени хабитус (или „карактер“/,нарав“ [make-up]) људи чини темељ, или оно што је Елијас (...) назвао тлом из којег личнија осећања могу да се развијају и расту. (Tuck 2003: 499)

Хабитус је блиско повезан са појмом идентитета, од кога се разликује по томе што „идентитет“ подразумева виши ниво освешћене свести чланова групе, неки степен рефлексије и артикулације, нека позитивна или негативна емоционална чувства према карактеристикама које чланови групе доживљавају као заједничке и у односу на које себе перципирају као различите од осталих група. (Mennell 1994: 177)

Сличност и разлика су динамички принципи идентификације који су у самом средишту људског света, а идентитет означава начине на које појединци и колективитети праве разлику у односу на друге појединце и колективитете (видети: Jenkins 2008: 18; Jenkins 2000).

\footnotetext{
${ }^{11}$ Habitus (лат. м. - држање, став [тела], спољашњост, изглед; ношња, одело; стање, положај, каквоћа, особеност; нахођење, расположење, мишљење), генеалогија овог концепта може да се, преко средњевековних схоластичара, прати до Аристотела (Sapiro 2015; Wacquant 2016) и његове категорије

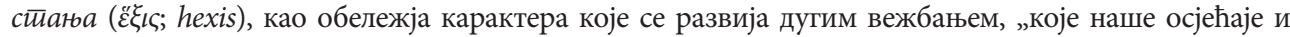
жудње усмјерава у даним ситуацијама и тиме утјече на наше изборе. Од уобичајене се склоности разликује стабилношћу и трајношћу“"(Protrka 2006: 943 n3).
} 


\section{Фигурације}

Социологија се, дакле, бави људима који су повезани у специфичне динамичне констелације које зовемо фигурацијама - „сложеним мрежама друштвених међузависности које прожимају свакодневни живот“ (Newton and Smith 2002: xi).

Слика човека као „затворене личности“ овде је замењена сликом човека као „отворене личности“ која поседује већи или мањи ступањ релативне (али никада апсолутне) самосталности у односу на друге људе, али човека који је током читавог живота упућен на друге људе и зависан од њих. Сплет упућености људи једних на друге, њихова међузависност, и јесте оно што људе повезује. Ове међузависности су окосница оног што овде називамо фигурацијом, то јест устројством у којем су људи упућени једни на друге и међузависни. Будући да су људи више или мање зависни једни од других најпре по природи, а онда учењем у друштву, одгојем, социјализацијом, и друштвено побуђеним узајамним потребама, они постоје, усудили бисмо се рећи, једино као плуралитети, искључиво у фигурацијама. (Елијас 2001: 42)

Отуда, за разлику од, горе поменутог, homo clausus-а у једнини, homines aperti - „отворени људи“ - постоје увек у множини (видети График 2). Елијас је инсистирао на овом моменту пошто је сматрао да људи могу да разумеју себе/сопствено делање само ако увиде да односи моћи одражавају сложено преплитање међузависности, где је агенсност лоцирана у мрежи (појединачних актера, група, држава), а не унутар посебних „суверених“ индивидуа: „Људи у ‘фигурацијама' чине једини агенс историјске промене“ (Sztompka 1994: 207).
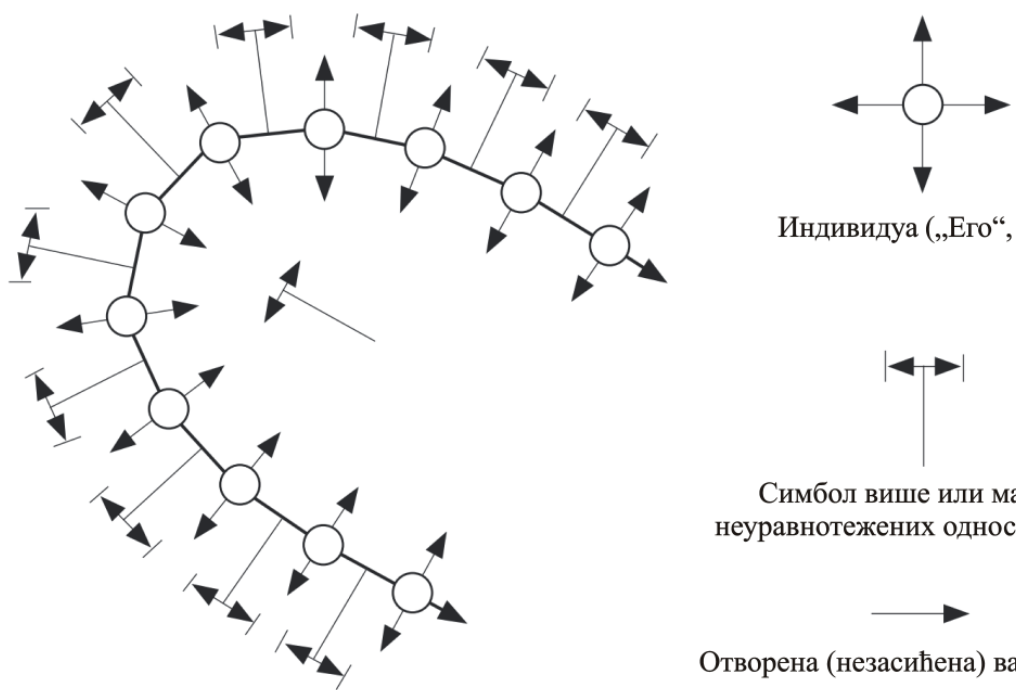

Индивидуа („Его“, ,ја“)

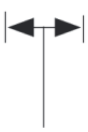

Симбол више или мање неуравнотежених односа моћи

Отворена (незасићена) валенција

График 2: Фигуращија међузависних индивидуа (,,породииа”, ,, држава”, ,група”, ,, друштво”, итд.)

(преузето из: Elias 1978: 15) 
Фигурације нису фиксиране, пошто су врло ретки односи моћи такви да осигуравају тоталну доминацију. Најчешће је у питању „игра“ сталног успостављања равнотеже између појединаца и група, где је моћ релациона - играчи ce, будући међузависни, увек узајамно контролишу (видети: Elias 1978: 81).

$$
\text { „Ја“ и ,мии“ идентитети }
$$

Елијас је као елементе који чине личност, односно лични идентитет, разликовао ,ја-идентитет“ и „ми-идентитет“ - „име“ и ,презиме“ са којима се индивидуа појављује пред другима. Људи стално успостављају равнотежу у свом идентитету између индивидуалног и групног. Судбина групе се, током времена, „таложи“ у хабитусу њених припадника - индивидуе (,,ja“) и група (,ми“) постају узајамно двоструко везани. ${ }^{12}$ „Индивидуе се остварују када друштвени контекст потпомаже, подржава или бар не спречава њихово слободно праћење својих структурних смерница“ (Bellini 2016: 382).

Ослањајући се на фигурацијски модел личних заменица (Elias 1978: 122128), Елијас показује како не би могло да постоји ,ја““ ако не постоји/-е други са којима је у односу. „Мора се имати на уму да бити свестан себе као особе за коју се каже ‘ја' претпоставља бивање свесним других људи као 'он', 'она', 'ми', ‘ти/ви' или 'они'“ (Elias 1978: 125).

Социјални контекст модерности фаворизује индивидуализам, те ,ја“ односи превагу над ,ми“.

Могућност, као и нужност, веће индивидуализације је аспект друштвене трансформације која је у великој мери изван контроле појединца. Производ ове све веће индивидуалности, веће разноликости појединих људи с обзиром на понашање, искуство и нарав, није једноставно природно дата у истом смислу као и разноликост људских тела. (...) Оно што се појављује (...) је одвојеност и затвореност појединаца у юиховим међусобним односима. (Elias 1991: 121)

Оваква ситуација доприноси поствареном виђењу сопственог положаја у свету, као „природно“ датог, непроменљивог и независног од друштвеног контекста (што је иронично, пошто управо друштвени контекст омогућује индивидуализам). На ово је указивао и Улрих Бек (Beck) у својим промишљањима индивидуализације у ризичном друштву касне модерности:

Како се људи у таласима индивидуализације ослобађају социјалних веза и приватизују, појављује се двоструки ефекат. Са једне стране, опажајне форме постају приватне, а у исто време и - замишљене у временској оси - неисто-

\footnotetext{
${ }^{12}$ Елијасов концептуални пар „ја-“ и „ми-идентитет“ подсећа на Мидово (Mead) разликовање „ја“ и „мене“ (“І”/“Ме”) као аспеката процеса стварања сопства, где је „ја“ непредвидив и креативан, а „мене“ његов конформистички аспект. „Ја“ је непосредна (често несвесна) реакција сопства на делања других (околину), а „мене“ свесно прихватање очекивања и жеља заједнице „уопштеног другог“(“generalized other”). Слично Елијасу, Мид је разматрао дуготрајну еволуцију људских друштава од примитивних у којима је „мене“ било доминантно, ка модерним где „ја“ има владајућу улогу (видети: Mead 1972: 354-378; Mead 2011).
} 
ријске. (...) То значи да се временски хоризонти животне перцепције све више сужавају, док се коначно у граничном случају историја не претвори у (вечну) садашњост и све не почне да се окреће око осе сопственог Ја, сопственог живота. Са друге стране, смањују се области где заједно артикулисано делање афирмише сопствени живот, а расту притисци да се сопствена биографија самостално обликује и то и тамо и управо тамо где није ништа друго до продукт односа. (Бек 2001: 230-231)

Елијас је био критички настројен према неисторијском приступању социјалним феноменима у друштвеним наукама, односно „повлачењу социолога у садашњост“ (Elias 1987). Сходно томе, он је и идентитет препознао као творевину у времену, која има историју, која је пресудна за његово разумевање.

\section{Идентитети као временска категорија}

Елијас је на (друштвени) живот гледао на процесуални начин, што за питање обликовања хабитуса, односно идентитета значи да је његово формирање сталан процес који траје током целог живота. Здраворазумски „поглед на живот и даље је психолошки везан за јучерашњу друштвену стварност, мада се данашња и сутрашња стварност већ увелико разликују од јучерашње“ (Elias 1995: 35). Оно што је суштинско (ако овде уопште можемо да говоримо о суштини) за идентитет није одређено стање (јучерашње, данашње, сутрашње), већ „континуитет промена“"

[У] многим процесима, јединство/целовитост процеса не чини било каква супстанца која остаје непромењена током процеса, већ континуитет у којем једна промена произлази из друге у непрекинутом редоследу. Узмите пример одређеног друштва, Холандије у петнаестом и двадесетом веку; оно што их повезује није толико језгро које остаје непромењено, већ континуитет промена кроз које је друштво двадесетог века произашло из онога из петнаестог века, наглашен чињеницом да је то континуитет који се памти. Узмите људско биће; Хјум је једном приликом признао да не може да разуме у којем је смислу он сада као одрасла особа „иста“ особа као мало дете које је некада био. Одговор је опет да идентитет није у тој мери ствар суштине, већ континуитет промена које воде из једне фазе у другу и, у овом случају, то је запамћени континуитет. Оно што у еволуцијском смислу називамо „животињским царством“ је континуитет промена: то је континуитет мноштва промена које повезују рибе са људима. Исто се може рећи и за физички универзум. Постоји много других примера. У свим тим случајевима, континуитет промена повезује каснију фазу са ранијим фазама. (Elias 1992: 220 n3)

Оваква перспектива омогућује разумевање промена (унутар) идентитета, увид у мењање размере учешћа ,ја“ и „ми“ компоненти, што отвара могућност и за скицирање вероватног тренда у будућности, уз подразумевану свест о комплексности и тешкој предвидивости друштвеног живота. 
Елијас даје једну динамичну и вишедимензионалну слику друштва. Његов рад карактерише „отвореност“ за комбиновање са другим теоријским приступима (Newton \& Smith 2002: ix), што свакако говори о великом аналитичком потенцијалу његове теорије.

Елијасово теоретисање снажно подстиче ка усредсређивању на сложене процесе који обликују „идентитетске преграде које постоје пре индивидуа, тако да се мишљење, психолошке карактеристике и схватање сопства формирају у дијалогу и у сукобу са оним што је већ унапред спремно и завештано“ (Wetherell 2010: 8-9). Према томе, немогућа је анализа „индивидуалне субјективности и животних путањи изван материјалних околности у којима се индивидуе налазе“" (Moore 2010: 2).

Посебан нагласак Елијас ставља на важност историјских и развојних процеса, што подрива тврдње о универзалности, безвремености/аисторичности и самоочигледности (наших) савремених појмова и представа који су, заправо, производ фигурација претходних нараштаја и које настављамо да (ре)конструишемо кроз тренутно постојеће мреже међузависности. Тако и идентитет није „унапред“, и ,једноставно“, дат, већ представља стално променљиви резултат преплитања односа унутар и међу фигурацијама током живота бројних генерација.

Можда је главна поента Елијасовог теоријског разматрања идентитета довођење у питање постојања јасне линије која дели „унутрашње сопство“ од „спољашњег света“, тако да се „наизглед стварно раздвајање себе и других, појединца и друштва, субјекта и објекта“ демаскира као „постварење друштвено подстакнутог занемаривања људског властитог искуства сопства““ (Elias 1978: $\left.122^{13}\right)$.

\section{Литература}

Бек, У. (2001) Ризично друштво: у сусрет новој модерни. Београд: Филип Вишњић. Бергсон, А. (2013) Материја и памћење: оглед о односу тела и духа. Београд: Федон.

Елијас, Н. (1988) „О повезаности контроле нагона и облика породице, односно друштвене структуре“"У А. Милић (ур.), Рађање модерне породище: Социолошка хрестоматија (стр. 154-160). Београд: Завод за уџбенике и наставна средства.

Елијас, Н. (2001) Процес иивилизаиије: сочиогенетичка и психогенетичка истражсивања. Сремски Карловци; Нови Сад: Издавачка књижарница Зорана Стојановића.

Елијас, Н. (2004) „'Нисмо научили да довољно контролишемо природу и себе’. Интервју са Норбертом Елиасом Интервју водила Афке Штинхис (Aafke Steenhuis)“, Журнал За Социологију 4: 103-114.

\footnotetext{
13 "[T]he apparently real partition between self and others, the individual and society, subject and object, is in fact a reification of the socially-instilled disengagement of their own self-experience."
} 
Елијас, Н. (2015) „Социологија знања: нове перспективе“ У Д. Маринковић \& Д. Ристић (прир.), Друштво и знање (стр. 286-313). Нови Сад: Mediterran Publishing.

Манхајм, К. (1978) Идеологија и утопија (друго издање). Београд: Нолит.

Манхајм, К. (2009) Есеји о социологији знаға. Нови Сад: Mediterran publishing

Маркс, К. (1964) Капитал: Критика политичке економије. Том 1. Кю. 1. [Део 2], Прочес капиталистичке производюе. Београд: Култура.

Bellini, P. P. (2016) "Identity and Social Roles: A Relational Perspective", Italian Sociological Review 6(3): 373-385. DOI: 10.13136/isr.v6i3.140.

Bourdieu, P. (2004) Science of Science and Reflexivity. Chicago: University of Chicago Press.

Conde, I. (2016) "Rethinking Individuals: New Figurations", Cambio. Rivista Sulle Trasformazioni Sociali 1: 42-55. DOI: 10.13128/cambio-19469.

Crossley, N. (2011) Towards Relational Sociology. New York, NY: Routledge.

Dépelteau, F. (Ed.). (2018) The Palgrave Handbook of Relational Sociology. Cham, Switzerland: Palgrave Macmillan.

Dépelteau, F., \& Landini, T. S. (2013) Norbert Elias and Social Theory from Classics to Contemporaries. Basingstoke: Palgrave Macmillan.

Dépelteau, F., \& Powell, C. (2014) Applying Relational Sociology: Relations, Networks, and Society. New York: Palgrave Macmillan.

Dunning, E., \& Hughes, J. (2013) Norbert Elias and Modern Sociology: Knowledge, Interdependence, Power, Process. London; New York: Bloomsbury Academic.

Elias, N. (1978) What is Sociology? London: Hutchinson.

Elias, N. (1987) “The Retreat of Sociologists into the Present”, Theory, Culture \& Society 4(2-3): 223-247. DOI: 10.1177/026327687004002003.

Elias, N. (1991) The Society of Individuals. New York: Continuum.

Elias, N. (1992) Time: An essay. Oxford: Blackwell.

Elias, N. (1995) “Technization and Civilization”, Theory, Culture \& Society 12(3): 7-42. DOI: $10.1177 / 026327695012003002$.

Elias, N. (2007) Što je sociologija? Zagreb: Antibarbarus.

Elias, N., Goudsblom, J., \& Mennell, S. (1998) The Norbert Elias Reader: A Biographical Selection. Oxford, UK; Malden, Mass: Blackwell Publishers.

Emirbayer, M. (1997) "Manifesto for a Relational Sociology", American Journal of Sociology 103(2): 281-317. DOI: 10.1086/231209.

Gordon, D. (2002) “The Canonization of Norbert Elias in France: A Critical Perspective”, French Politics, Culture \& Society 20(1): 68-94. DOI: 10.3167/153763702782369957.

Goudsblom, J. (1977) Sociology in the Balance: A Critical Essay. New York: Columbia University Press.

Heinich, N. (2002) La sociologie de Norbert Elias. Paris: Éditions La Découverte \& Syros.

Jenkins, R. (2000) "Categorization: Identity, Social Process and Epistemology", Current Sociology 48(3): 7-25. DOI: 10.1177/0011392100048003003. 
Jenkins, R. (2008) Social identity ( $3^{\text {rd }}$ ed). London; New York: Routledge.

Kilminster, R. (2007) Norbert Elias: Post-philosophical Sociology. London; New York: Routledge, Taylor \& Francis Group.

Landini, T. S., \& Dépelteau, F. (2014) Norbert Elias and Empirical Research. New York: Palgrave Macmillan.

Landini, T. S., \& Dépelteau, F. (Eds.). (2017) Norbert Elias and Violence. New York: Palgrave Macmillan.

Law, A. (2015) Social Theory for Today: Making Sense of Social Worlds. Los Angeles: SAGE.

Marx, K. (1979) Dela. T. 19, [Osnovi kritike političke ekonomije: (Ekonomski rukopisi 1857-1859)], deo 1. Beograd: Institut za međunarodni radnički pokret; Prosveta.

Mead, G. H. (1972) Mind, Self, and Society: From the Standpoint of a Social Behaviorist. Chicago; London: University of Chicago Press.

Mead, G. H. (2011) “The Social Self”. In F. C. da Silva (Ed.), G. H. Mead: A Reader (58-62). London; New York: Routledge.

Mennell, S. (1992) Norbert Elias: An Introduction. Oxford: Blackwell.

Mennell, S. (1994) "The Formation of We-Images: A Process Theory". In C. J. Calhoun (Ed.), Social Theory and the Politics of Identity (175-197). Cambridge, MA: Blackwell Publishers.

Merton, R. K. (1936) “The Unanticipated Consequences of Purposive Social Action”, American Sociological Review 1(6): 894-904. DOI: 10.2307/2084615.

Moore, A. (2010) “'I' and 'We' Identities - an Eliasian Perspective on Lesbian and Gay Identities", Sociological Research Online 15(4): 1-8. DOI: 10.5153/sro.2241.

Newton, T., \& Smith, D. (2002) "Introduction: Norbert Elias and the Civilized Organization" In A. van Iterson, W. Mastenbroek, T. Newton, \& D. Smith (Eds.), The Civilized Organization: Norbert Elias and the Future of Organization Studies (vii-xxviii). Amsterdam; Philadelphia: John Benjamins Publishing Company.

Popper, K. R. (2002) Conjectures and Refutations: The Growth of Scientific Knowledge. London; New York: Routledge.

Powell, C. J., \& Dépelteau, F. (2013) Conceptualizing Relational Sociology: Ontological and Theoretical Issues. New York: Palgrave Macmillan.

Protrka, M. (2006) „Tijelo-habitus-hexis. Pierre Bourdieu i mogućnost intervencije u strukturu polja“, Filozofska istraživanja 26(4): 941-951.

Quilley, S., \& Loyal, S. (2005) “Eliasian Sociology as a 'Central Theory' for the Human Sciences”, Current Sociology 53(5): 807-828. DOI: 10.1177/0011392105055021.

Sapiro, G. (2015) "Habitus: History of a Concept" In N. J. Smelser \& P. B. Baltes (Eds.), International Encyclopedia of the Social \& Behavioral Sciences (484-489). DOI: 10.1016/B978-0-08-097086-8.03085-3.

Simmel, G. (2009) Sociology: Inquiries into the Construction of Social Forms. Leiden; Boston: Brill.

Smith, D. (2001) Norbert Elias and Modern Social Theory. London; Thousand Oaks: SAGE Publications. 
Sztompka, P. (1994) The Sociology of Social Change. Oxford, UK ; Cambridge, Mass: Blackwell.

Tuck, J. (2003) "Making Sense of Emerald Commotion: Rugby Union, National Identity and Ireland", Identities 10(4): 495-515. DOI: 10.1080/714947402.

Van Krieken, R. (1998) Norbert Elias. London; New York: Routledge.

Wacquant, L. (2016) “A Concise Genealogy and Anatomy of Habitus", The Sociological Review 64(1): 64-72. DOI: 10.1111/1467-954X.12356.

Wetherell, M. (2010) “Introduction” In The SAGE Handbook of Identities (pp. 2-26). London: SAGE. DOI: 10.4135/9781446200889.n1.

\section{AFFIRMATION OF THE SOCIOLOGICAL APPROACH TO IDENTITY IN THE THEORY OF NORBERT ELIAS}

Abstract: The paper deals with identity as a process, a concept that was strongly advocated by Norbert Elias. His "process sociology" was an endeavor to overcome the dualities that burdened sociological theory. Elias launched a critique of reification of social structure as an object outside and independent of the individual. At the same time, Elias dismissed what he called homo clausus (a concept in which emphasis is put on autonomy, freedom and independence of the actor) as excessive individualism, where society is understood as an intended outcome of individual action(s). In his theory of identity Elias, amongst others, used concepts of habitus, figuration, 'I-' and 'We-identities'. He referred to habitus as 'second nature' or 'an automatic blindly functioning apparatus of self-control', experienced on the individual level as a personality structure, but collectively authored and reproduced in a life long process. Elias recognized individual identity as a temporal creation. His perspective permits the analysis of the changes in the 'I-We' relation, without giving precedence to either of the elements of this pair. Also, identity is conceived as multiperspectival (relational) and shaped by the figurations (interdependency chains).

Key Words: Process, Identity, Habitus, Figuration, 'I-' and 'We-Identities'. 
